\title{
DETERMINAN YANG MEMPENGARUHI INDEKS PENGUNGKAPAN SUKARELA PADA LAPORAN TAHUNAN PERBANKAN DI BURSA EFEK INDONESIA TAHUN 2014-2016
}

\author{
Ichda Rachmawati ${ }^{1}$ Alfiyani Nur Hidayanti ${ }^{2}$ \\ Program Studi Akuntansi, Fakultas Ekonomi dan Bisnis, Universitas Muria Kudus \\ ${ }^{1}$ ichda6896@gmail.com \\ 2alfiyani.nur@umk.ac.id
}

\begin{abstract}
ABSTRAK
Penelitian ini bertujuan untuk menguji hubungan ukuran perusahaan, ukuran kantor akuntan publik, usia listing, dan rasio likuiditas terhadap indeks pengungkapan sukarela. Data yang digunakan adalah data sekunder laporan tahunan perbankan yang terdaftar di Bursa Efek Indonesia tahun 2014-2016. Teknik pengambilan sampel menggunakan purposive sampling. Metode analisis menggunakan analisis regresi linier berganda. Hasil penelitian menunjukkan bahwa ukuran perusahaan, ukuran kantor akuntan publik dan rasio likuiditas berpengaruh positif sedangkan usia listing tidak berpengaruh terhadap indeks pengungkapan sukarela.
\end{abstract}

Kata Kunci : ukuran perusahaan, indeks pengungkapan sukarela

\section{ABSTRACT}

This study aims to firm size, size of public accounting firm, age of listing, and liquidity ratio to voluntary disclosure index. The data used is secondary data obtained from the annual report of banking listed in Indonesia Stock Exchange period 2014-2016. Sampling technique using purposive sampling. Analysis method using multiple linear regression analysis. The result show that firm size, size of public accountany office, and liquiditty ratio have a positive effect also that age of listing did not affect the voluntary disclosure index.

Keyword : firm size, voluntary disclosure index

\section{PENDAHULUAN}

Laporan keuangan merupakan produk akhir akuntansi dan media utama penyampaian informasi oleh manajemen kepada stakeholder. Bagi manajemen laporan keuangan dijadikan sebagai alat pertanggungjawaban atas wewenang yang dimilikinya. Kualitas informasi keuangan tercermin pada sejauh mana luas pengungkapan laporan yang diterbitkan perusahaan (Haryanto dkk, 2012).

Menurut Hidayat (2016) Informasi yang tertera dalam laporan tahunan terdiri dari pengungkapan wajib (mandatory disclosure) dan pengungkapan sukarela (voluntary disclosure). Mandatory disclosure merupakan pengungkapan yang diwajibkan oleh peraturan yang berlaku sebagaimana telah ditetapkan dalam Pernyataan Standar Akuntansi 
Keuangan (PSAK). Voluntary disclosure merupakan pengungkapan yang tidak diwajibkan, sehingga perusahaan bebas memilih jenis informasi yang akan diungkapkan.

Walaupun tidak ada lembaga berwenang yang mengatur tentang pengungkapan sukarela, namun terdapat teori yang menjelaskan tentang adanya pengungkapan informasi tambahan yang dilakukan oleh perusahaan. Agency Theory memberikan penjelasan mengenai pengungkapan informasi yang dilakukan perusahaan. Hubungan keagenan merupakan suatu kontrak dimana satu atau lebih pihak (principal) memperkerjakan pihak lain (agent) untuk melaksanakan beberapa pengambilan keputusan principal kepada agent (Puruwita, 2012). Adapula Signaling Theory yang melandasi adanya pengungkapan sukarela dimana manajemen selalu berusaha untuk mengungkapkan informasi privat yang menurut pertimbangannya sangat diminati oleh investor dan pemegang saham khususnya kalau informasi tersebut merupakan berita baik (good news) (Soewardjono 2005: 583).

Penelitian ini memfokuskan kepada pengungkapan sukarela (voluntary disclosure) dengan menggunakan data laporan tahunan. Beberapa faktor yang mempengaruhi indeks pengungkapan sukarela yaitu ukuran perusahaan, ukuran kantor akuntan publik, usia listing, dan rasio likuiditas. Faktor pertama yaitu ukuran perusahaan. Ukuran perusahaan adalah suatu skala dimana dapat diklasifikasikan besar kecilnya perusahaan (Wiguna, 2012). Hasil penelitian yang dilakukan oleh Hidayat (2017) menunjukkan bahwa ukuran perusahaan berpengaruh positif terhadap indeks pengungkapan sukarela. Kedua adalah ukuran akuntan publik yang merupakan ukuran badan usaha yang telah mendapatkan izin sesuai perundang-undangan yang berusaha dibidang pemberian jasa professional praktik akuntan publik. Ketiga adalah usia listing yaitu seberapa lama perusahaan terdaftar di Bursa Efek Indonesia (BEI) sebagai perusahaan go pubic. Faktor keempat yaitu rasio likuiditas kemampuan suatu perusahaan untuk memenuhi kewajiban finansial yang segera harus terpenuhi (Riyanto, 2008:25).

Alasan peneliti memilih determinan yang mempengaruhi indeks pengungkapan sukarela ini karena adanya research gap pada peneliti terdahulu, dan objek penelitian perbankan dikarenakan perbankan merupakan termasuk lima sektor yang diminati investor saham dari data yang dihimpun forexsignal pada Februari 2017.

Berdasarkan latar belakang diatas penulis tertarik untuk meneliti determinan yang mempengaruhi indeks pengungkapan sukarela. Penelitian ini bertujuan untuk menguji dan menganalisis secara empiris pengaruh positif ukuran perusahaan, ukuran kantor akuntan publik, usia listing, dan rasio likuiditas terhadap indeks pengungkapan sukarela pada 
laporan tahunan perbankan di Bursa Efek Indonesia tahun 2014-2016. Hasil penelitian ini diharapkan dapat memberikan manfaat bagi akademisi untuk memberikan referensi, bagi perbankan, yang dapat menjadi bahan pertimbangan pihak manajemen perusahaan dalam melakukan pengungkapan sukarela, dan bagi stakeholder, yang dapat dijadikan pertimbangan dalam pengambilan keputusan saat akan berinvestasi.

\section{TINJAUAN PUSTAKA}

\section{Landasan Teori}

\section{Teori Agensi}

Jensen dan Meckling (1976) menjelaskan teori agensi merupakan teori yang mendeskripsikan hubungan keagenan yaitu suatu kontrak dimana satu atau lebih orang (prinsipal) memerintah orang lain (agen) untuk melakukan suatu jasa atas nama prinsipal serta memberi wewenang kepada agen membuat keputusan yang terbaik bagi prinsipal. Jika kedua belah pihak tersebut mempunyai tujuan yang sama untuk memaksimumkan nilai perusahaan, maka diyakini agen akan bertindak dengan cara yang sesuai dengan kepentingan principal.

Hidayat (2017) berpendapat bahwa principal memiliki informasi yang cukup tentang kinerja agen. Agen memiliki lebih banyak informasi mengenai kapasitas diri, lingkungan kerja, dan prospek perusahaan secara keseluruhan di masa yang akan datang dibandingkan dengan principal. Hal ini yang menyebabkan ketidakseimbangan informasi yang dimiliki oleh principal dan agen. Ketidakseimbangan inilah yang disebut sebagai asimetri informasi. Dengan adanya pengungkapan sukarela maka diharapkan akan dapat mengurangi asimetri informasi tersebut.

\section{Teori Stakeholder}

Teori lain yang mendukung penelitian ini adalah teori stakeholder. Menurut Ghozali dan Chariri (2007:409), teori stakeholder merupakan teori yang menjelaskan bahwa perusahaan bukanlah entitas yang hanya beroperasi untuk kepentingan sendiri namun harus memberikan manfaat bagi stakeholder (pemegang saham, kreditor, konsumen, supplier, pemerintah, masyarakat, analis, dan pihak lain).

\section{Teori Sinyal}

Menurut Ross (1977), teori sinyal merupakan teori yang menyatakan bahwa pihak eksekutif perusahaan memiliki informasi lebih baik mengenai perusahaannya akan terdorong untuk menyampaikan informasi tersebut kepada calon investor agar harga saham 
perusahaannya meningkat. Teori sinyal adalah suatu tindakan yang diambil manajemen perusahaan yang memberi petunjuk bagi investor tentang bagaimana manajemen memandang prospek perusahaan (Brigham dan Houston, 2006:38). Vernando dan Halmawati (2016) menyatakan manajemen selalu berusaha untuk mengungkapan informasi privat yang menurut pertimbangannya sangat diminati oleh investor dan pemegang saham khususnya kalau informasi tersebut merupakan berita baik (good news).

\section{Laporan Tahunan}

Laporan tahunan merupakan laporan perkembangan pencapaian keberhasilan yang mampu diraih oleh suatu perusahaan dalam jangka waktu satu tahun. Laporan tahunan adalah suatu dokumen yang diterbitkan tiap tahun suatu perusahaan yang berisi laporan keuangan yang telah diperiksa oleh akuntan publik dan didalamnya terdapat laporan keuangan perusahaan termasuk informasi tambahan mengenai perusahaan dan produknya serta hal-hal yang berkaitan dengan usaha perusahaan selama satu tahun. Sesuai dengan surat keputusan ketua BAPEPAM No. Kep.134/BL/2006 Tanggal 7 Desember 2006, maka tentang laporan tahunan ini wajib dikeluarkan bagi perusahaan yang telah melakukan penawaran umum dan perusahaan publik.

\section{Indeks Pengungkapan Sukarela}

Indeks pengungkapan sukarela merupakan pengungkapan butir-butir informasi pilihan manajemen yang dilakukan secara sukarela tanpa diwajibkan oleh peraturan yang berlaku. Informasi yang terkandung tersebut harus lengkap, jelas dan dapat menggambarkan secara tepat mengenai kejadian-kejadian ekonomi yang berpengaruh terhadap hasil operasi unit usaha (Vernando dan Halmawati, 2016).

\section{Ukuran Perusahaan}

Ukuran perusahaan merupakan suatu skala dimana dapat diklasifikasikan besar kecilnya perusahaan. Perusahaan yang besar cenderung akan mengungkapkan lebih banyak informasi daripada perusahaan yang kecil. Hal tersebut terkait dengan teori agensi yang mencegah terjadinya asimetri informasi serta mengurangi biaya keagenan yang mencegah terjadinya asimetri informasi serta mengurangi biaya keagenan yang ditimbulkan oleh asimetri informasi (Wiguna, 2012). Menurut Haryanto dan Yunita (2012) mengungkapkan perusahaan yang berukuran lebih besar cenderung memiliki public demand akan informasi yang lebih tinggi dibanding dengan perusahaan yang lebih kecil. Perusahaan kecil umumnya berada pada situasi persaingan yang ketat dengan perusahaan yang lain. 


\section{Ukuran Kantor Akuntan Publik}

Kantor Akuntan Publik (KAP) adalah badan usaha yang telah mendapatkan izin sesuai dengan peraturan perundang-undangan yang berusaha dibidang pemberian jasa professional praktik akuntan publik. Menurut Hidayat (2017) ukuran KAP yang mengaudit perusahaan berpengaruh secara signifikan terhadap luas pengungkapan perusahaan.Perusahaan yang laporan keuangannya diaudit oleh KAP yang termasuk dalam The Big Four dianggap lebih luas dalam pengungkapannya. Perusahaan yang menggunakan Kantor Akuntan Publik besar (the big four) maka laporan keuangan yang diterbitkan perusahaan tersebut akan memiliki tingkat kepercayaan yang lebih tinggi. Manajemen mengeluarkan laporan keuangan tahunan diperiksa dan dinilai oleh auditor sebagai pihak luar yang independen.

\section{Usia Listing}

Usia listing perusahaan merupakan seberapa lama perusahaan terdaftar di Bursa Efek Indonesia (BEI) sebagai perusahaan go public. Iklim perusahaan yang semakin ketat mempengaruhi manajemen perusahaan dalam mengendalikan perkembangan dunia usaha (Vernando dan Halmawati, 2016). Menurutnya juga perusahaan yang memiliki umur yang lebih lama sebagai perusahaan go public memiliki lebih banyak pengalaman dalam mengungkapkan informasi yang dibutuhkan pihak berkepentingan dalam laporan tahunan perusahaan. Perusahaan yang terdaftar di Bursa Efek Indonesia (BEI) cenderung akan melakukan pelaporan keuangannya secara lebih transparan dan jelas dibandingkan dengan perusahaan-perusahaan yang tidak atau belum terdaftar di BEI. Hal tersebut disebabkan perusahaan yang sudah lama listing di BEI memiliki lebih banyak pengalaman dalam mempublikasikan laporan keuangannya.

\section{Rasio Likuiditas}

Riyanto (2008:25) menyatakan bahwa likuiditas adalah masalah yang berhubungan dengan masalah kemampuan suatu perusahaan untuk memenuhi kewajiban finansialnya yang segera harus dipenuhi. Suatu perusahaan yang mempunyai alat-alat likuid sedemikian besarnya sehingga mampu memenuhi segala kewajiban finansial yang segera harus terpenuhi, dikatakan bahwa perusahaan tersebut likuid, dan sebaliknya apabila suatu perusahaan tidak mempunyai alat-alat likuid yang cukup untuk memenuhi segala kewajiban finansialnya yang segera harus terpenuhi dikatakan perusahaan tersebut insolvable. 


\section{Kerangka Pemikiran}

Gambar 2.1 Kerangka Pemikiran

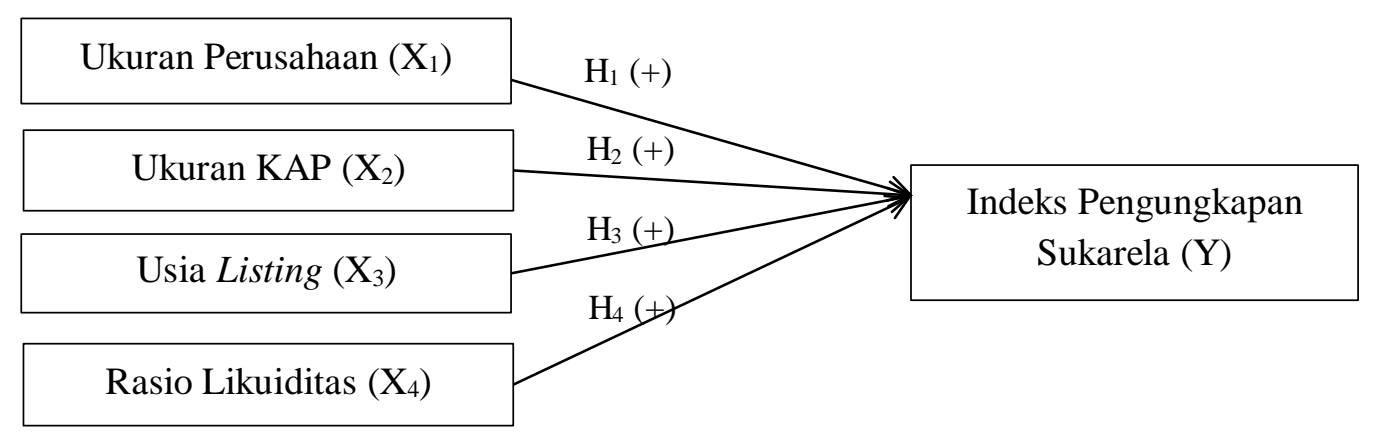

Sumber: Hidayat (2017) dan Haryanto \& Yunita (2012) yang telah dimodifikasi

\section{Pengembangan Hipotesis}

\section{Pengaruh Ukuran Perusahaan Terhadap Indeks Pengungkapan Sukarela}

Ada dua teori yang melandasi hipotesis yakni teori stakeholder dan teori sinyal. Keduanya melatarbelakangi mengapa ukuran perusahaan penting untuk diungkapkan untuk memenuhi kebutuhan stakeholder bagaimana perusahaan sudah berkembang. Penelitian yang dilakukan Haryanto dan Yunita (2012) mengungkapkan perusahaan yang berukuran lebih besar cenderung memiliki public demand akan informasi yang lebih tinggi dibanding dengan perusahaan yang lebih kecil.

Dengan demikian, hipotesis dapat dirumuskan sebagai berikut:

\section{$\mathrm{H}_{1}$ : Ukuran perusahaan berpengaruh positif terhadap indeks pengungkapan} sukarela

\section{Pengaruh Ukuran Kantor Akuntan Publik Terhadap Indeks Pengungkapan Sukarela}

Teori keagenan menyatakan agar hubungan kontraktual ini dapat berjalan dengan lancar, pemilik mendelegasikan otoritas pembutan keputusan kepada manajer begitu pula dalam hal pengauditan perusahaan oleh sebuah KAP. Sehingga opini yang didapat oleh perusahaan dapat dilihat dan dianalisis oleh stakeholder, sesuai dengan teori stakeholder. Sehingga benar yang dikatakan oleh teori sinyal bahwa segala informasi seperti ukuran KAP sangat penting untuk diungkapkan oleh perusahaan. Hidayat (2017) mengatakan jika Perusahaan yang laporan keuangannya diaudit oleh KAP yang termasuk dalam The Big Four dianggap lebih luas dalam pengungkapannya.

Jadi, dapat diambil suatu hipotesis sebagai berikut:

$\mathbf{H}_{2}$ : Ukuran KAP berpengaruh positif terhadap indeks pengungkapan sukarela 


\section{Pengaruh Usia Listing Terhadap Indeks Pengungkapan Sukarela}

Berkaitan dengan teori stakeholder, perusahaan yang sudah lama terdaftar dalam Bursa Efek Indonesia akan memberikan informasi sebanyak mungkin kepada para stakeholder untuk memperlihatkan kondisi perusahaannya. Selain itu berkaitan dengan teori sinyal, perusahaan yang telah lama terdaftar di BEI akan terdorong untuk memberikan informasi yang sejelas mungkin memberikan kejelasan bagi investor sehingga dapat menarik lebih banyak investor lain. Perusahaan yang memiliki umur yang lebih lama sebagai perusahaan go public memiliki lebih banyak pengalaman dalam mengungkapkan informasi yang dibutuhkan pihak berkepentingan dalam laporan tahunan perusahaan.

Dengan demikian, hipotesis yang diambil adalah sebagai berikut:

H3: Usia Listing berpengaruh positif terhadap indeks pengungkapan sukarela

\section{Pengaruh Rasio Likuiditas Terhadap Indeks Pengungkapan Sukarela}

Berkaitan dengan teori stakeholder, perusahaan yang memiliki rasio yang tingggi akan memberikan informasi sebanyak mungkin kepada para stakeholder untuk memperlihatkan kondisi perusahaannya. Selain itu berkaitan dengan teori sinyal, perusahaan yang rasio likuiditas baik akan terdorong untuk memberikan informasi yang sejelas mungkin memberikan kejelasan bagi investor sehingga dapat menarik lebih banyak investor lain. Penelitian yang telah dilakukan oleh Haryanto dan Yunita (2012) menyatakan jika likuiditas perusahaan yang kuat akan lebih mengungkapkan informasi daripada perusahaan-perusahaan yang lemah.

Sehingga, hipotesis yang bisa diambil oleh penulis adalah sebagai berikut:

$\mathbf{H}_{4}$ : Rasio Likuiditas berpengaruh positif terhadap indeks pengungkapan sukarela.

\section{METODE PENELITIAN}

\section{Definisi Operasional}

\section{Variabel Dependen}

Variabel dependen yaitu variabel yang nilai-nilainya bergantung pada variabel lainnya atau mempengaruhi variabel independen, biasanya disimbolkan dengan huruf Y dan merupakan variabel yang diramalkan atau diterangkan nilainya (Hasan., 2009). Dalam penelitian ini menggunakan variabel dependen yaitu Indeks Pengungkapan Sukarela (Y). 


\section{Variabel Independen}

Variabel independen yaitu variabel yang nilai-nilainya tidak tergantung pada variabel penelitian lainnya atau dipengaruhi variabel dependen, biasanya disimbolkan dengan huruf X (Hasan, 2009). Dalam penelitian ini menggunakan variabel independen yaitu ukuran perusahaan $\left(\mathrm{X}_{1}\right)$, ukuran kantor akuntan publik $\left(\mathrm{X}_{2}\right)$, usia listing $\left(\mathrm{X}_{3}\right)$, dan rasio likuiditas $\left(\mathrm{X}_{4}\right)$

\section{Pengukuran Variabel}

Pengukuran masing-masing variabel dapat digambarkan dalam tabel sebagai berikut:

Tabel 3.1 Pengukuran Variabel

\begin{tabular}{|l|l|l|}
\hline No & Variabel & Rumus \\
\hline 1 & Indeks Pengungkapan Sukarela & IPS $=\frac{n}{K}$ \\
\hline 2 & Ukuran Perusahaan & Ln(Total Asset) \\
\hline 3 & Ukuran KAP & $\begin{array}{l}1 \text { Untuk KAP Big Four, 0 untuk KAP non big } \\
\text { four }\end{array}$ \\
\hline 4 & Usia Listing & $\begin{array}{l}\text { Usia Listing = Tahun Sampel - Tahun awal } \\
\text { listing di BEI }\end{array}$ \\
\hline 5 & Rasio Likuiditas & Rasio Likuiditas= Aset Lancar \\
\hline
\end{tabular}

\section{Populasi dan Sampel}

Populasi dalam penelitian ini adalah perbankan yang terdaftar dan mempublikasikan laporan tahunannya di BEI tahun 2014-2016. Pemilihan sampel dilakukan dengan metode purposive sampling. Teknik pengambilan sampel purposive merupakan teknik penentuan sampel dengan pertimbangan khusus seperti kriteria-kriteria sehingga layak dijadikan sampel (Noor, 2012). Kriteria yang diambil adalah sebagai berikut:

1. Perusahaan yang terdaftar di Bursa Efek Indonesia mulai dari tahun 2014-2016 secara berturut-turut.

2. Perusahaan mempublikasikan laporan keuangan dan dapat ditemukan pada website BEI pada tahun 2014-2016.

3. Laporan keuangan perusahaan menggunakan mata uang rupiah.

4. Laporan keuangan yang memiliki kelengkapan data terkait variabel-variabel yang digunakan 
Tabel 3.2 Pemilihan Sampel

\begin{tabular}{|l|c|c|c|}
\hline Keterangan & $\mathbf{2 0 1 4}$ & $\mathbf{2 0 1 5}$ & $\mathbf{2 0 1 6}$ \\
\hline Perbankan yang terdaftar di BEI pada tahun 2014-2016 & 40 & 42 & 43 \\
\hline $\begin{array}{l}\text { (-)Perusahaan tidak mempublikasikan laporan keuangan dan } \\
\text { tidak dapat ditemukan pada website BEI pada tahun 2014- } \\
2016\end{array}$ & $(1)$ & - & $(1)$ \\
\hline (-) Laporan keungan tidak menggunakan mata uang rupiah & - & - & - \\
\hline $\begin{array}{l}\text { (-)Laporan keuangan yang tidak memiliki kelengkapan data } \\
\text { terkait variabel-variabel yang digunakan }\end{array}$ & $(4)$ & $(7)$ & $(7)$ \\
\hline Jumlah Sampel & $\mathbf{3 5}$ & $\mathbf{3 5}$ & $\mathbf{3 5}$ \\
\hline Sampel akhir untuk pengujian & \multicolumn{3}{|c|}{$\mathbf{1 0 5}$} \\
\hline
\end{tabular}

Sumber: Data yang diolah sendiri oleh peneliti

\section{Pengolahan Data}

Data-data yang telah dikumpulkan diolah menggunakan program SPSS 23.0. Selanjutnya, dilakukan analisis data sebagai berikut:

\section{Analisis Data}

Metode analisis yang digunakan dalam menguji variabel-variabel dalam penelitian ini adalah analisis statistik deskriptif, yang nantinya akan didapatkan nilai rata-rata (mean), median, standar deviasi, nilai minimum, nilai maksimum, varian dan standard deviasi (Ghozali, 2016: 19). Selain itu, akan dilakukan uji asumsi klasik yakni uji normalitas data, uji multikolonieritas, uji heterokedastisitas, dan uji autikorelasi. Analisis menggunakan analisis regresi linier berganda dan uji hipotesis dengan menggunakan uji koefisien determinasi, uji signifikansi simultan $\mathrm{F}$, dan uji signifikan parameter individual (uji statistik t).

\section{HASIL DAN PEMBAHASAN}

\section{Statistik Deskriptif}

Tabel 4.1 Hasil Statistik Deskriptif

\begin{tabular}{|l|r|r|r|r|}
\hline & Minimum & Maximum & Mean & Std. Deviation \\
\hline IPS & 0,18 & 0,68 & 0,4345 & 0,11961 \\
\hline Ukuran Perusahaan & 28,13 & 35,95 & 31,2936 & 1,81018 \\
\hline Ukuran KAP & 0 & 1 & 0,5619 & 0,49853 \\
\hline Usia Listing & 0 & 34 & 11,5810 & 9,00724 \\
\hline Rasio Likuiditas & 0,67 & 1,53 & 1,1435 & 0,09966 \\
\hline
\end{tabular}

Sumber: Data sekunder yang diolah dengan SPSS 23, 2018

Ukuran perusahaan memiliki nilai minimum atau paling sedikit sebesar 28,13 dan nilai maksimum atau dalam penelitian ini paling besar 35,95. Nilai mean atau rata-rata ukuran perusahaan sebesar 31,2936 dengan standar deviasi 1,81018. Nilai rata-rata lebih besar dari standar deviasinya menunjukkan bahwa hasil yang baik dan penyebaran datanya merata, sehingga yang termasuk ukuran perusahaan banyak. 
Ukuran Kantor Akuntan Publik (KAP) memiliki nilai minimum sebesar 0 menunjukkan bahwa perusahaan tidak di audit oleh KAP Big Four dan nilai maksimum 1 menunjukkan bahwa perusahaan yang di audit oleh KAP Big Four. Nilai mean sebesar 0,5619 menunjukkan bahwa rata-rata Kantor Akuntan Publik yang digunakan dalam penelitian ini adalah KAP Big Four dengan standar deviasi sebesar 0,49853. Nilai rata-rata lebih besar dari standar deviasinya menunjukkan bahwa hasil yang baik.

Usia listing memiliki nilai minimum sebesar 0 menunjukkan bahwa usia paling perusahaan saat listing terendah dan nilai maksimum adalah 34 menunjukkan bahwa paling tinggi usia perusahaan saat listing di Bursa Efek Indonesia. Nilai mean sebesar 11,5810 menunjukkan bahwa rata-rata usia listing dalam penelitian ini adalah 11 dengan standar deviasi sebesar 9,00724. Nilai rata-rata lebih besar dari standar deviasinya menunjukkan bahwa hasil yang baik.

Rasio likuiditas memiliki nilai minimum sebesar 0,67 menunjukkan bahwa dalam penelitian ini current ratio perusahaan paling sedikit dan nilai maksimum 1,53 menunjukkan bahwa dalam penelitian ini current ratio perusahaan paling besar. Nilai mean sebesar 1,1435 menunjukkan bahwa rata-rata current ratio dengan standar deviasi 0,09966 dan nilai standar deviasi lebih kecil dari mean maka penyebaran datanya merata, sehingga perusahaan rasio likuiditas besar.

\section{Uji Asumsi Klasik}

\section{Uji Normalitas}

\section{Gambar 4.1 Normal P-Plot}

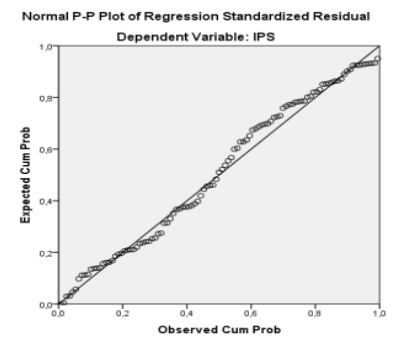

Untuk lebih memastikan bahwa data residual telah terdistribusi secara normal, maka dilakukan pengujian dengan Kolmogorov-smironov yang disajikan berikut ini:

Tabel 4.2 Hasil Kolmogorov-smironov

\begin{tabular}{|l|r|}
\hline & $\begin{array}{c}\text { Unstandardized } \\
\text { Residual }\end{array}$ \\
\hline $\mathrm{N}$ & 105 \\
Test Statistic & 0,077 \\
Asymp. Sign. (2-tailed) & 0,131 \\
\hline
\end{tabular}

Sumber: Data sekunder yang diolah dengan SPSS 23, 2018 


\section{P ISSN \\ [ACCOUNTING GLOBAL JOURNAL] E ISSN}

Hasil uji menggunakan Kolmogorov-Smirnov menunjukkan nilai test statistic Kolmogorov-Smirnov sebesar 0,077 dengan tingkat probabilitas sebesar 0,131 maka dapat disimpulkan bahwa data residual terdistribusi secara normal.

\section{Uji Multikolonieritas}

Tabel 4.3 Hasil Uji Multikolonieritas

\begin{tabular}{|c|c|c|}
\hline \multirow[t]{2}{*}{ Variabel } & \multicolumn{2}{|c|}{$\begin{array}{c}\text { Collinearity } \\
\text { Statistic }\end{array}$} \\
\hline & Tolerance & VIF \\
\hline Ukuran Perusahaan & 0,611 & 1,636 \\
\hline Ukuran KAP & 0,724 & 1,381 \\
\hline Usia Listing & 0,694 & 1,440 \\
\hline Rasio Likuiditas & 0,981 & 1,020 \\
\hline
\end{tabular}

Hasil uji multikolonieritas menunjukkan bahwa tidak ada satupun variabel bebas yang memiliki tolerance kurang dari 0,10 dan tidak ada nilai Variance Inflation Factor (VIF) di atas 10. Jadi dapat disimpulan bahwa tidak terjadi adanya multikolonieritas antar variabel independen dalam model regresi ini.

\section{Uji Heterokedastisitas}

Gambar 4.2 Hasil Scatterplot

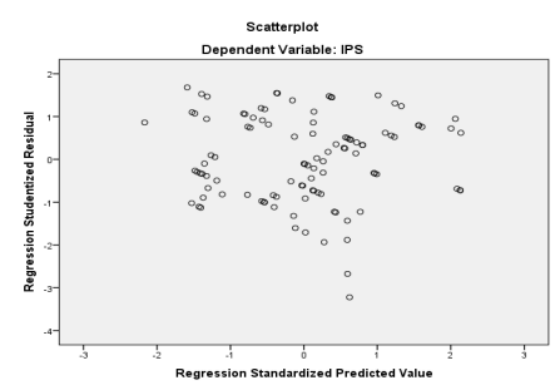

Tabel 4.4 Hasil Uji Glejser

\begin{tabular}{|l|l|}
\hline Variabel & Sign. \\
\hline Ukuran Perusahaan & 0,207 \\
Ukuran KAP & 0,244 \\
Usia Listing & 0,537 \\
Rasio Likuiditas & 0,897 \\
\hline
\end{tabular}

Sumber: Data sekunder yang diolah menggunakan SPSS 23, 2018

Secara simultan nilai signifikan lebih dari 0,05 . Hal ini dapat disimpulkan bahwa dalam model regresi pada penelitian ini tidak terjadi heterokedastisitas. 


\section{[ACCOUNTING GLOBAL JOURNAL] E ISSN}

\section{Uji Autokorelasi}

Tabel 4.5 Hasil Run Test

\begin{tabular}{|l|r|}
\hline & Unstandardized Residual \\
\hline Asymp. Sign. (2-tailed) & 0,281 \\
\hline
\end{tabular}

Sumber: Data sekunder yang diolah menggunakan SPSS 23, 2018

Berdasarkan hasil uji autokorelasi data dengan menggunakan uji Run Test di atas didapatkan hasil probabilitas 0,281 lebih besar dari 0,05. Hal ini menunjukkan bahwa dalam model regresi ini telah terbebas dari masalah autokorelasi.

\section{Hasil Uji Persamaan Regresi Linier Berganda}

\section{Tabel 4.6 Regresi Linier}

\begin{tabular}{|l|r|}
\hline Variabel & Koefisien \\
\hline (Constant) & $-0,808$ \\
Ukuran Perusahaan & 0,032 \\
Ukuran KAP & 0,069 \\
Usia Listing & $-0,003$ \\
Rasio Likuiditas & 0,206 \\
\hline
\end{tabular}

Sumber: Data sekunder yang diolah menggunakan SPSS 23, 2018

Dari tabel dapat dirumuskan suatu persamaan regresi untuk mengetahui pengaruh ukuran perusahaan, ukuran kantor akuntan publik, usia listing dan rasio likuiditas terhadap indeks pengungkapan sukarela sebagai berikut:

$$
\text { IPS }=-0,808+0,032 \text { UP + 0,069 KAP }-0,003 \mathrm{UL}+0,206 \mathrm{CR}+\varepsilon
$$

\section{Uji Hipotesis}

\section{Uji Koefisien Determinasi $\left(\mathbf{R}^{2}\right)$}

Tabel 4.7 Hasil Uji Koefisien Determinasi $\mathbf{R}^{2}$

\begin{tabular}{|c|l|l|l|}
\hline $\mathrm{R}$ & $\mathrm{R}$ Square & $\begin{array}{c}\text { Adjusted R } \\
\text { Square }\end{array}$ & $\begin{array}{c}\text { Std. Error of the } \\
\text { Estimate }\end{array}$ \\
\hline 0,618 & 0,382 & 0,358 & 0,09587 \\
\hline
\end{tabular}

Sumber: Data sekunder yang diolah menggunakan SPSS 23, 2018

Hal ini menunjukkan bahwa Adjust $R^{2}$ menggambarkan variasi perubahan asimetri informasi sekitar 36\% dapat dijelaskan oleh pengungkapan sukarela. Sedangkan sisanya $64 \%$ dijelaskan oleh variabel lain.

\section{Uji Signifikansi Simultan (Uji Statistik F)}

Tabel 4.8 Hasil Signifikansi Simultan F

\begin{tabular}{|l|r|r|r|r|r|}
\hline Model & Sum of Squares & df & Mean Square & F & Sig. \\
\hline Regression &, 569 & 4 &, 142 & 15,477 &, $000^{\mathrm{b}}$ \\
Residual &, 919 & 100 &, 009 & & \\
Total & 1,488 & 104 & & & \\
\hline
\end{tabular}

Sumber: Data sekunder yang diolah menggunakan SPSS 23, 2018 
Dari uji ANOVA atau Uji $\mathrm{F}$ hasil probabilitas signifikansi yang menunjukkan 0,000. Nilai probabilitas pengujian lebih kecil dari 0,05 . Hal ini menunjukkan bahwa secara bersama-sama (simultan) indeks pengungkapan sukarela dipengaruhi oleh kepemilikan asing, kepemilikan pemerintah, ukuran perusahaan, ukuran kantor akuntan publik, usia listing dan rasio likuiditas.

\section{Uji Signifikansi Parameter Individual (Uji Statistik t)}

Tabel 4.9 Hasil Uji Statistik $t$

\begin{tabular}{|l|l|l|l|}
\hline Variabel & T & Sign. & Keterangan \\
\hline Ukuran Perusahaan & 4,808 & 0,000 & Diterima \\
Ukuran KAP & 3,098 & 0,003 & Diterima \\
Usia Listing & $-2,163$ & 0,033 & Ditolak \\
Rasio Likuiditas & 2,167 & 0,033 & Diterima \\
\hline
\end{tabular}

Sumber: Data sekunder yang diolah menggunakan SPSS 23, 2018

\section{KESIMPULAN}

Berdasarkan hasil penelitian dan pembahasan yang telah dilakukan, maka dapat ditarik kesimpulan sebagai berikut:

\section{Pengaruh Ukuran Perusahaan Terhadap Indeks Pengungkapan Sukarela}

Hasil penelitian mendapatkan hasil positif dan berpengaruh signifikan terhadap indeks pengungkapan sukarela pada perbankan yang terdaftar di Bursa Efek Indonesia pada tahun 2014-2016. Jadi bisa dikatakan semakin besar ukuran suatu perusahaan akan semakin banyak pengungkapan informasi secara sukarela yang diberikan oleh perbankan. Hasil penelitian ini sejalan dengan penelitian yang dilakukan oleh Hidayat (2017), Baskaraningrum dan Merkusiwati (2012), serta Haryanto dan Yunita (2012). Namun bertolak belakang dengan hasil yang didapatkan oleh Wiguna (2012) yang menyatakan ukuran perusahaan tidak berpengaruh terhadap indeks pengungkapan sukarela.

\section{Pegaruh Ukuran Kantor Akuntan Publik (KAP) Terhadap Indeks Pengungkapan Sukarela}

Hasil penelitian mendapatkan hasil positif dan berpengaruh signifikan terhadap indeks pengungkapan sukarela pada perbankan yang terdaftar di Bursa Efek Indonesia pada tahun 2014-2016. Jadi bisa dikatakan apabila perusahaan di audit oleh The Big Four dan afiliasinya maka akan semakin banyak pengungkapan sukarela yang diungkapkan karena dapat mempengaruhi hasil audit yang di dapat. Hasil penelitian ini sejalan dengan penelitian yang dilakukan oleh Hidayat (2017). 


\section{Pengaruh Usia Listing Terhadap Indeks Pengungkapan Sukarela}

Hasil penelitian mendapatkan hasil negatif dan tidak berpengaruh terhadap indeks pengungkapan sukarela pada perbankan yang terdaftar di Bursa Efek Indonesia pada tahun 2014-2016. Jadi bisa dikatakan perusahaan yang sudah lama terdaftar ataupun yang baru terdaftar di Bursa Efek Indonesia tidak mempengaruhi luasnya pengungkapan sukarela yang diungkapkan dalam laporan keuangan. Hasil penelitian ini sejalan dengan penelitian yang dilakukan oleh Vernando dan Halmawati (2016). Namun bertolak belakang dengan penelitian yang dilakukan Hidayat (2017) yang menyatakan usia listing berpengaruh terhadap indeks pengungkapan sukarela.

\section{Pengaruh Rasio Likuiditas Terhadap Indeks Pengungkapan Sukarela}

Hasil penelitian mendapatkan hasil positif dan berpengaruh signifikan terhadap indeks pengungkapan sukarela pada perbankan yang terdaftar di Bursa Efek Indonesia pada tahun 2014-2016. Jadi bisa dikatakan semakin baik rasio likuiditasnya maka akan mempengaruhi luasnya pengungkapan sukarela yang diungkapkan dalam laporan keuangan. Hasil penelitian ini sejalan dengan penelitian yang dilakukan oleh Haryanto dan Yunita (2012). Namun bertolak belakang dengan penelitian yang dilakukan Merkusiwati (2012) yang menyatakan rasio likuiditas tidak berpengaruh terhadap indeks pengungkapan sukarela.

\section{Keterbatasan}

Penelitian ini tentunya masih terdapat beberapa keterbatasan. Keterbatasanketerbatasan tersebut diantaranya adalah sebagai berikut:

1. Variabel independen ukuran perusahaan, ukuran Kantor Akuntan Publik, usia listing, dan rasio likuiditas hanya mampu menjelaskan 36\% variasi indeks pengungkapan sukarela sedangkan sisanya $64 \%$ dijelaskan variabel-variabel diluar penelitian, sehingga masih diperlukan untuk penambahan variabel lain.

2. Pada penelitian ini yang menjadi objek penelitian hanya perbankan yang terdaftar di Bursa Efek Indonesia. Hal ini belum bisa menggambarkan semua perbankan yang ada di Indonesia.

\section{Saran}

Adapun beberapa saran bagi peneliti yang akan datang sebagai berikut:

1. Diharapkan menambah variabel lain yaitu profitabilitas dan leverage. Penambahan variabel profitabilitas didasari pada pemikiran bahwa pengungkapan sejauh mana 
efektivitas laba yang dihasilkan dari modal yang digunakan oleh perusahaan, selain itu bisa ditambahkan leverage, karena investor juga mempertimbangkan sejauh mana operasi perusahaan dibiayai dengan hutang (Haryanto dan Yunita, 2012).

2. Diharapkan dapat memperluas objek penelitian pada perbankan yang ada di Indonesia, sehingga dapat diketahui luas indeks pengungkapan sukarela pada perbankan di Indonesia.

\section{DAFTAR PUSTAKA}

Baskaraningrum, Made Ratih dan Ni Ketut Lely A Merkusiwati. 2012. "Pengungkapan Sukarela Laporan Keuangan Tahunan dan Faktor-faktor yang Mempengaruhi (Studi pada Saham-saham LQ45 di Bursa Efek Indonesia Periode 2010-2011). Jurnal Fakultas Ekonomi Universitas Udayana. Bali.

Brigham, Eugene F. \& Houtson, Joel F. 2006. Dasar-dasar Manajemen Keuangan. Jakarta: Salemba Empat.

Ghozali, Imam, 2016. Aplikasi Analisis Multivarite dengan SPSS, Cetakan Kedelapan, Semarang: Badan Penerbit Universitas Diponegoro.

Ghozali, Imam dan Anis Chariri, 2007. Teori Akuntansi. Semarang: Badan Penerbit Universitas Diponegoro.

Hasan, Iqbal, 2009. Analisis Data Penelitian Statistik. Jakarta: Bumi Aksara.

Hidayat, Muhammad. 2017. "Faktor-Faktor yang Mempengaruhi Pengungkapan Sukarela pada Laporan Tahunan Sektor Perbankan di Bursa Efek Indonesia", Jurnal Riset Akuntansi Indonesia, Vol6(1): h:151-172.

IAI, 2009. Standar Akuntansi Keuangan. Jakarta: Salemba Empat.

Jensen \& Meckling, 1976, The Theory of the Firm: Managerial Behavior, Agency Costs and Ownership Structure, Journal if Finansial and Economics, Vol 3:305-360.

Keputusan Ketua Badan Pengawas Pasar Modal BAPEPAM No. SE-02/PM/2002 Mengenai Pedoman Penyajian dan Pengungkapan Laporan Keuangan Emiten.

Noor, Juliansyah, 2012. Metodologi Penelitian Skripsi, Tesis, Disertasi, dan Karya Ilmiah. Jakarta: Kencana Prenada Media Group.

Pernyataan Standar Akuntansi Keuangan (PSAK).

Puruwita, Rr Wardani, 2012. "Faktor-faktor yang Mempengaruhi Luas Pengungkapan Sukarela", Jurnal Akuntansi dan Keuangan.Vol. 14 (1).

Riyanto, Bambang, 2008. Dasar-dasar Pembelajaran Perusahaan, Yogyakarta: BPFE.

Ross, S. (1977). The Determination of Finansial Structure: The Incentive-Signaling Approach. The Bell Journall of Economics,

Vernando, Rahmat Yoga dan Halmawati. 2016. "Pengaruh Ownership Dispersion,

Finansial Distressed, dan Umur Listing Terhadap Luas Pengungkapan Sukarela:

Studi pada Perusahaan Manufaktur yang Terdaftar di BEI Tahun 2012-2014”, Jurnal WRA. Vol 4(1).

Wiguna, Putu Wisnu. 2012. "Pengaruh Leverage, Ukuran Perusahaan, Profitabilitas dan Likuiditas pada Luas Pengungkapan Sukarela”. Jurnal Fakultas Ekonomi Universitas Udayana. Bali.

Yunita, Ira dan Haryanto. 2012. "Analisis Likuiditas, Leverage, Ukuran Perusahaan dan Profitabilitas terhadap Pengungkapan Sukarela Laporan Keuangan (Studi Empiris Pada Perusahaan Real Estate)". Jurnal Fakultas Ekonomi, Universitas Diponegoro, Semarang. 